\title{
Short-term stabilization of organic matter in physically, chemically, and biochemically protected pools in soils amended with municipal wastes
}

José M. Fernández, Esther G. López-de-Sá, Alfredo Polo, and César Plaza *

Instituto de Ciencias Agrarias, Consejo Superior de Investigaciones Científicas, Serrano 115 bis, 28006 Madrid, Spain

Running title: Organic matter stabilization in soils amended with municipal wastes

Correspondence: C. Plaza, Instituto de Ciencias Agrarias, Consejo Superior de Investigaciones Científicas, Serrano 115 dpdo., 28006 Madrid, Spain.

E-mail: c.plaza@,ica.csic.es

\begin{abstract}
Abbreviations: MC, soil amended with municipal solid waste compost; MSW, municipal solid waste; OM, organic matter; SC, soil amended with sewage sludge compost; SS, sewage sludge; TS, soil amended with thermally dried sewage sludge; UN, unameded control soil.
\end{abstract}

Keywords: Municipal solid waste compost; Physical fractionation; Sewage sludge; Soil aggregates; Soil organic matter. 


\section{Abstract}

2

3 Increased understanding of the stabilization mechanisms of the organic matter (OM)

4 entering the soil system through the application of organic amendments is of paramount

5 agronomic and environmental importance. Here we examined the organic $\mathrm{C}$ and total $\mathrm{N}$

6 distribution in $\mathrm{OM}$ pools (i.e., free, intra-macroaggregate, intra-microaggregate,

7 mineral-associated, dissolved, and humic acid fractions) characterized by different

8 protection mechanisms in soils annually amended with different organic substrates of

9 municipal origin (i.e., municipal solid waste compost, sewage sludge compost, and

10 thermally dried sewage sludge) for three years. With respect to the unamended control

11 soil, the application of the three organic materials, especially thermally dried sewage

12 sludge, increased soil organic $\mathrm{C}$ and total $\mathrm{N}$ contents. The organic inputs accumulated

13 mostly in the physically unprotected free OM pool, as relatively fresh, low humified

14 materials, and secondarily in the intra-macroaggregate fraction, as partially decomposed

15 OM weakly protected by physical mechanisms. Our results suggest that mechanisms

16 related to strong physical protection in microaggregates and chemical inaccessibility by

17 intimate association with minerals do not govern OM stabilization in the short term. 


\section{Introduction}

Preserving soil organic matter (OM) is crucial to maintain soil functioning in agricultural ecosystems. Soil OM not only plays a central role in soil processes that govern crop production and supports the growth of a variety of animals and microorganisms, but also preserves water quality and influences atmospheric concentrations of greenhouse gases at a global scale [1-3].

Soil amendment with treated municipal wastes, such as municipal solid waste (MSW) compost and sewage sludge (SS), is widely backed as a means to improve soil fertility and replenish, preserve, or increase soil OM content $[4,5]$. Decomposition of OM inputs into the soil is determined by biological and environmental conditions [2] and a combination of biochemical, physical, and chemical mechanisms of protection within the soil matrix. These mechanisms refer to inherent biochemical recalcitrance and formation of structures more resistant to degradation (e.g., humic substances and black carbon), physical protection in macro and microaggregates, and chemical association to minerals [6-8].

A large number of studies in the literature on the stabilization of organic materials in soils have focused on the biochemical protection mechanisms, examining quantitative and qualitative changes in humified OM pools (especially in humic acid fractions) using chemical fractionation methods and characterization techniques [9-11]. These studies indicate that (a) organic amendments generally increase soil humified OM pools, as well as non-humic pools, to an extent that depends on the quantity and quality of the organic input; (b) organic amendments, especially non-composted "fresh" materials, determine significant changes in the molecular composition and functionalities of the isolated humic fractions in the short term; and (c) the composition and functional 
properties of humic pools in amended soils do not differ significantly from those of native soil humic pools in the long term [9-11].

Other studies have tried to capture the role of the formation of primary and secondary organomineral complexes in the stabilization of organic inputs in the soil matrix using physical fractionation procedures [12-15]. In particular, Courtier-Murias et al. [16] recently fractionated soil OM pools from long-term (44-year-old) amended field plots by means of a physical procedure that is believed to be well linked to the current concepts of soil OM preservation mechanisms and advantageous for the molecular characterization of the isolated fractions [17, 18]. Most of the increases in soil OM stocks observed in the amended soils with respect to the unamended control were explained by the OM pool intimately associated with soil minerals, which was found to be predominately of microbial origin, followed by the intra-microaggreggate $\mathrm{OM}$ fraction, which were dominated by plant structures at relatively advanced stages of decomposition. The findings of this study were strongly consistent with the theory that microbes and microbial residues play a central role in soil $\mathrm{OM}$ stabilization and sequestration, inasmuch as it is not the intact or partially degraded plant materials, fragments, and tissues that are preserved in soil in the long term, but the microbial structures and microbial derived by-products resulting from OM transformation and degradation processes [16, 18-23].

Long-term studies are needed to assess the sustainability of agricultural systems and $\mathrm{C}$ sequestration following soil management change scenarios; nevertheless, stabilization and mineralization processes of OM inputs may significantly affect soil fertility, quality, and functioning in the short term. In this context, the objective of this work was to test whether OM from treated municipal organic wastes of different quality entering the soil are stabilized in a relatively short term by the same aforementioned mechanisms 
observed in the long term for other organic materials (i.e., chemical association of microbes and microbial by-products with mineral surfaces and physical protection by entrapment within small microaggregates). For this purpose, we examined the organic $\mathrm{C}$ and $\mathrm{N}$ distribution in $\mathrm{OM}$ pools characterized by different protection mechanisms in soils amended with MSW compost, SS compost, and thermally dried SS for three years. We used a physical fractionation method to isolate free, intra-macroaggregate, intramicroaggregate, mineral-associated, and dissolved OM pools, and a classic chemical fractionation approach to isolate humic acids.

\section{Materials and methods}

\subsection{Field experiment and sampling}

\section{The field experiment was established in 2008 at Arganda del Rey, Madrid, Spain} $\left(40^{\circ} 19^{\prime} \mathrm{N}, 3^{\circ} 29^{\prime} \mathrm{W}, 535 \mathrm{~m}\right.$ above sea level). The climate of this site is Mediterranean. The average annual rainfall is $436 \mathrm{~mm}$ and average annual temperature of $14{ }^{\circ} \mathrm{C}$. The soil is classified as a Xerofluvent and has a clay loam texture [24]. Before initiation of the experiment, the site had been under intensive crop production.

The experimental plots $(7.5 \mathrm{~m}$ by $3 \mathrm{~m})$ were laid out in a randomized complete block design with four treatments and four replicates. The treatments consisted of a control with no amendment and either MSW compost, SS compost, or thermally dried $\mathrm{SS}$ applied at a rate of $30 \mathrm{t}^{\text {ha }}$ year $\mathrm{r}^{-1}$ for three consecutive years; this rate of organic amendment is traditional in the study area. Hereafter, UN is used for unamended soil, MC for soil amended with MSW compost, SC for soil amended with SS compost, and 
93 TS for soil amended with thermally dried SS. The MSW compost and the SS compost

94 were produced using a conventional windrow composting system at waste treatment

95 facilities located in Toledo and Madrid, respectively. The thermally-dried SS was

96 produced by heating SS with a stream of hot air at $380-450{ }^{\circ} \mathrm{C}$ at a wastewater treatment

97 plant located in Madrid. The three amendments were hand broadcast in late October and

98 immediately incorporated into the upper $15 \mathrm{~cm}$ of soil with a rotary tiller. The cropping

99 system was a three year rotation of winter wheat (Triticum aestivum L.), sunflower

100 (Helianthus annuus L.), and winter barley (Hordeum vulgare L.).

101 Samples of MSW compost, SS compost, and thermally dried SS were taken at the

102 time of application and ground with a ball mill for organic $\mathrm{C}$ and total $\mathrm{N}$ determination.

103 Soil samples representative of the plow layer (0-15-cm depth) were collected randomly

104 from each plot in late June 2011, just after barley harvest. The soil samples were gently

105 crushed and passed through a 2-mm sieve for physical fractionation. An aliquot of each

106 sieved sample was ground with a ball mill for chemical fractionation (humic acid

107 extraction) and organic $\mathrm{C}$ and total $\mathrm{N}$ analyses.

108

109

2.2 Physical fractionation

110

Physical fractionation of soil OM was conducted according to the procedure of

112 Plaza et al. [17] with modifications as described in detail by Plaza et al. [18]. This

113 procedure is mainly based on the densimetric method of Golchin et al. [25] and Sohi et

114 al. [26] for the fractionation of free and occluded OM and the procedure of Six et al.

$115[27,28]$ for the breakup of macroaggregates preserving microaggregates. In brief, free

116 OM was separated by density flotation in a NaI solution and subsequent suction and

117 filtration. Macroaggregates in the remaining soil were broken up by using the 
microaggregate isolator device developed by Six et al. [27, 28] for liberating intramacroaggregate OM, which was then recovered by a second density separation. Finally, intra-microaggregate $\mathrm{OM}$ was isolated from mineral-associated OM by a third density separation after ultrasonic disruption. Here NaI was used for density separations instead of sodium polytungstate as reported in Plaza et al. [17, 18], because sodium polytungstate may contain some $\mathrm{N}$ that inevitably remains in the heavy fraction after the last separation and hampers the examination of $\mathrm{N}$ distribution. The recovered free, intramacroaggregate, intra-microaggregate, and mineral-associated OM fractions were ovendried at $70{ }^{\circ} \mathrm{C}$, weighed, and ground with a ball mill.

\subsection{Chemical fractionation}

Soil humic acids were extracted on the basis of their acid-base properties by means of a classic chemical fractionation procedure [29]. Briefly, a solution of $\mathrm{Na}_{4} \mathrm{P}_{2} \mathrm{O}_{7}$ and $\mathrm{NaOH}$ was added to soil samples at a weight-to-volume ratio of 1 to 3, shaken mechanically, and centrifuged. This procedure was repeated three times on the residues. The alkaline extracts were combined, acidified with $\mathrm{HCl}$, and centrifuged. The humic acid precipitates were recovered with distilled water, dialyzed, and freeze-dried.

\subsection{Organic $\mathrm{C}$ and total $\mathrm{N}$ determination}

The organic $\mathrm{C}$ and total $\mathrm{N}$ contents of the organic amendments, whole soil samples, and OM fractions were determined by dry combustion with a Thermo Flash 2000 NC Soil Analyzer. The acid fumigation method described by Harris et al. [30] was used to remove carbonates from the organic amendments, whole soil samples, and mineral- 
(1)

associated OM fractions before the analysis. The results were expressed on a dry soil weight basis. Dissolved organic C and $\mathrm{N}$ contents (dissolved OM pool) were estimated by subtracting the free, intra-aggregate, and mineral-associated organic $\mathrm{C}$ and $\mathrm{N}$ contents from the total organic $\mathrm{C}$ and $\mathrm{N}$ contents in the whole soil. Soil humic acid $\mathrm{C}$ content was determined according to the method of Ciavatta et al. [31], which is based on the same acid-base fractionation procedure described above for humic acid extraction. To calculate the soil humic acid $\mathrm{N}$ content, the soil humic acid $\mathrm{C}$ content determined by the method of Ciavatta et al. [31] was divided by the humic acid $\mathrm{C} / \mathrm{N}$ ratio determined by dry combustion on the freeze-dried humic acid samples.

\subsection{Statistical analysis}

5

Dependent variables (organic $\mathrm{C}$ contents, total $\mathrm{N}$ contents, and $\mathrm{C} / \mathrm{N}$ ratios of whole soil samples, and OM fractions) were subjected to one-way ANOVA to test whether the effects of the experimental treatments were significant. The Bonferroni test at the 0.05 level was used for mean separation. These statistical calculations were performed with the IBM SPSS 20 software.

\section{Results and discussion}

\section{The main chemical properties of the MSW compost, SS compost, and thermally} dried SS applied to the soil are shown in Table 1. In agreement with data reported in previous studies [32-36], the thermally dried SS has $15 \%$ more organic C and 58\% more $\mathrm{N}$ than the MSW compost, and 50\% more organic C and $48 \%$ more $\mathrm{N}$ that the SS 
compost. Compared to the values found for both kinds of SS, the $\mathrm{C} / \mathrm{N}$ ratio of MSW compost is higher and closer to the $\mathrm{C} / \mathrm{N}$ ratio of the soil (Table 1 ).

With respect to the control treatment, the application of the three organic materials significantly increases soil organic $\mathrm{C}$ and total $\mathrm{N}$ contents and tends to decrease soil $\mathrm{C} / \mathrm{N}$ ratio after 3 years (Table 2). Numerous studies in the literature report accrued organic $\mathrm{C}$ and $\mathrm{N}$ contents in organically amended soils compared with unamended soils, the magnitude of the effect depending on a variety of factors, such as the amendment rate, soil type, and climate $[13,37-40]$. Here the highest increases in organic $\mathrm{C}$ and total $\mathrm{N}$ contents are observed in TS, followed by $\mathrm{MC}$ and $\mathrm{SC}$, while the lowest $\mathrm{C} / \mathrm{N}$ ratio was observed in $\mathrm{MC}$. The percent of organic $\mathrm{C}$ added with the amendment that is stored in the soil decreases in the order $\mathrm{SC}>\mathrm{TS}>\mathrm{MC}$, whereas the percent of added total $\mathrm{N}$ stored in the soil decreases in the order MC $>$ SC $>$ TS. Previous results obtained by laboratory incubation with measurement of respired C, chemical (elemental analysis) and spectroscopic (infrared and nuclear magnetic resonance) methods, and thermal analysis techniques (thermogravimetry and differential scanning calorimetry) indicated that the OM in thermally dried SS is less stable than that in MSW and SS compost [34]. There are data in the literature showing that the amount of organic $\mathrm{C}$ stored in amended soils is not dependent on the type of residue applied [37, 38]. However, other works suggest that undecomposed organic materials (e.g., fresh plant residues) are less efficient at building up soil OM than relatively more stable amendments (e.g., manures and composts) $[16,41]$.

The free, intra-macroaggregate, intra-microaggregate, mineral-associated, and dissolved organic $\mathrm{C}$ and total $\mathrm{N}$ contents in the unamended and amended soils are shown in Figures 1 and 2, respectively. As found in other studies [16, 18, 25, 42], the mineral-associated $\mathrm{OM}$ is the most abundant organic $\mathrm{C}$ pool, constituting $65 \%$ of the 
total soil organic C in UN, $53 \%$ in SC, $52 \%$ in MC, and 44\% in TS; similarly, the mineral-associated OM fraction accounts for the greatest proportion of the total $\mathrm{N}$ in the soils examined, with contributions of $68 \%$ in $\mathrm{UN}, 60 \%$ in $\mathrm{SC}, 54 \%$ in $\mathrm{MC}$, and $48 \%$ in TS.

Treatment effects were significant on free organic $\mathrm{C}$ and total $\mathrm{N}(P<0.001)$, intramacroaggregate organic $\mathrm{C}$ and $\mathrm{N}(P<0.05)$, and dissolved $\mathrm{N}(P<0.05)$, and not significant $(P>0.05)$ on dissolved organic $\mathrm{C}$ and intra-microaggregate and mineralassociated organic $\mathrm{C}$ and total $\mathrm{N}$. In particular, with respect to the unamended soil, the application of thermally dried SS, MSW compost, and SS compost significantly increases free and intra-macroaggregate organic C by 223 and 196\%, 192 and 159\%, and 126 and $39 \%$, respectively, and free total $\mathrm{N}$ by 419,308 , and $205 \%$, respectively. In the three amended soils, the free OM pool accounts for most of the increase in total organic $\mathrm{C}$ content measured with respect to the unamended soil. In particular, this fraction explains 69,55 , and $61 \%$ of the total organic $\mathrm{C}$ increase in $\mathrm{MC}, \mathrm{SC}$, and TS soils, respectively. These results clearly differ from those of Courier-Murias et al. [16], who reported that the mineral-associated OM fraction, followed by the intramicroaggreggate $\mathrm{OM}$ pool, explains most of the increase in total organic $\mathrm{C}$ content in soils amended with manure and crop residues for 44 years.

The $\mathrm{C} / \mathrm{N}$ ratio of the solid OM pools in the unamended soil decreases in the order free $\mathrm{OM}>$ intra-macroaggregate $\mathrm{OM}>$ intra-microaggregate $\mathrm{OM}>$ mineral-associated OM (Figure 3), passing from a value of 18, typical of plant residues, to a value of 9 , indicative of greater degree of OM decomposition and associated with an enrichment in microbial derived materials $[1,19]$. The $\mathrm{C} / \mathrm{N}$ ratio of the free $\mathrm{OM}$ pool in the amended soils, especially with thermally dried SS, is significantly smaller than that of the unamended soil and relatively closer to the $\mathrm{C} / \mathrm{N}$ ratios of the organic amendments 
(Figure 3). In contrast, no significant differences among treatments are found in the mineral-associated and dissolved OM pools, and only the application of MSW compost slightly decrease the $\mathrm{C} / \mathrm{N}$ ratio of the intra-aggregate fractions (Figure 3 ).

Humic acid $\mathrm{C}$ and $\mathrm{N}$ contents increase with the application of the organic amendments, especially with the composted materials (Figures 1 and 2). The $\mathrm{C} / \mathrm{N}$ ratios of the humic acid fractions in the amended soils, especially in the soil treated with thermally dried SS, are significantly smaller than that of the unamended soil (Figure 3). The $\mathrm{C} / \mathrm{N}$ ratios of humic acid-like fractions present in organic amendments are typically smaller than those of native soil humic acids, indicative of lower humification degree [9-11]. Thus, consistently with previous studies on similar systems [9-11; 42], our results suggest a partial incorporation of simple and low humified components into the humic acid pools of the amended soils.

\section{Concluding remarks}

$$
\text { Annual soil amendment for three consecutive years with organic materials derived }
$$
from different municipal organic wastes increased soil OM content. Regardless of their chemical composition, the organic inputs accumulated mostly in the unprotected free OM pool, as relatively fresh, low humified materials, and secondarily in the intramacroaggregate fraction, as partially decomposed OM weakly protected by physical mechanisms. Most likely, stabilization mechanisms related to strong physical protection in microaggregates and chemical inaccessibility by intimate association with minerals would become more and more important in longer periods of time. This warrants further investigation. Extensive research is also needed to unravel the links between short- and 
243 long-term stabilization of municipal organic wastes in the soil matrix and their

244 composition, the treatments applied to stabilize them prior to application, and their

245 effects on soil fertility, quality, and functioning. 
246 Acknowledgements

247

248 This work was supported by the Spanish Ministry of Science and Innovation

249 (research grant AGL2009-09124). José Manuel Fernańdez was the recipient of a

250 fellowship from the CSIC JAE-DOC (Junta de Ampliacion de Estudios) program

251 cofinanced by the European Social Fund.

252

253

The authors have declared no conflict of interest. 


\section{References}

[1.] F. J. Stevenson, Humus Chemistry: Genesis, Composition, Reactions, 2nd ed., John Wiley \& Sons, New York, NY 1994.

[2.] M. W. I. Schmidt, M. S. Torn, S. Abiven, T. Dittmar, G. Guggenberger, I. A. Janssens, M. Kleber, I. Kogel-Knabner, J. Lehmann, D. A. C. Manning, P. Nannipieri, D. P. Rasse, S. Weiner, S. E. Trumbore, Persistence of Soil Organic Matter as an Ecosystem Property, Nature 2011, 478, 49-56.

[3.] U. Stockmann, M. A. Adams, J. W. Crawford, D. J. Field, N. Henakaarchchi, M. Jenkins, B. Minasny, A. B. McBratney, V. d. R. d. Courcelles, K. Singh, I. Wheeler, L. Abbott, D. A. Angers, J. Baldock, M. Bird, P. C. Brookes, C. Chenu, J. D. Jastrow, R. Lal, J. Lehmann, A. G. O’Donnell, W. J. Parton, D. Whitehead, M. Zimmermann, The Knowns, Known Unknowns and Unknowns of Sequestration of Soil Organic Carbon, Agric. Ecosyst. Environ. 2013, 164, 8099.

[4.] R. A. Düring, S. Gäth, Utilization of Municipal Organic Wastes in Agriculture: Where Do We Stand, Where Will We Go?, J. Plant Nutr. Soil Sci. 2002, 165, 544-556.

[5.] M. Diacono, F. Montemurro, Long-Term Effects of Organic Amendments on Soil Fertility. A Review, Agron. Sustain. Dev. 2010, 30, 401-422.

[6.] P. Sollins, P. Homann, B. A. Caldwell, Stabilization and Destabilization of Soil Organic Matter: Mechanisms and Controls, Geoderma 1996, 74, 65-105.

[7.] J. Six, R. T. Conant, E. A. Paul, K. Paustian, Stabilization Mechanisms of Soil Organic Matter: Implications for C-Saturation of Soils, Plant Soil 2002a, 241, 155-176. 
279 [8.] M. Von Lützow, I. Kögel-Knabner, K. Ekschmitt, E. Matzner, G. Guggenberger, B. Marschner, H. Flessa, Stabilization of Organic Matter in Temperate Soils: Mechanisms and their Relevance under Different Soil Conditions - A Review, Eur. J. Soil Sci. 2006, 57, 426-445.

[9.] N. Senesi, T. M. Miano, G. Brunetti, Humic-Like Substances in Organic Amendments and Effects on Native Soil Humic Substances, in Humic Substances in Terrestrial Ecosystems (Ed.: A. Piccolo), Elsevier, New York, NY 1996, pp. 531-593.

[10.] N. Senesi, C. Plaza, Role of Humification Processes in Recycling Organic Wastes of Various Nature and Sources as Soil Amendments, CLEAN-Soil Air Water 2007, 35, 26-41.

[11.] N. Senesi, C. Plaza, G. Brunetti, A. Polo, A Comparative Survey of Recent Results on Humic-Like Fractions in Organic Amendments and Effects on Native Soil Humic Substances, Soil Biol. Biochem. 2007, 39, 1244-1262.

[12.] M. H. Gerzabek, G. Haberhauer, H. Kirchmann, Soil organic matter pools and carbon-13 natural abundances in particle-size fractions of a long-term agricultural field experiment receiving organic amendments, Soil Sci. Soc. Am. J. 2001, 65, 352-358.

[13.] E. E. Marriott, M. M. Wander, Total and Labile Soil Organic Matter in Organic and Conventional Farming Systems, Soil Sci. Soc. Am. J. 2006, 70, 950-959.

[14.] D. C. Olk, E. G. Gregorich, Overview of the Symposium Proceedings, "Meaningful Pools in Determining Soil Carbon and Nitrogen Dynamics", Soil Sci. Soc. Am. J. 2006, 70, 967-974.

[15.] A. Y. Y. Kong, J. Six, Tracing Root vs. Residue Carbon into Soils from Conventional and Alternative Cropping Systems, Soil Sci. Soc. Am. J. 2010, 74, 
[16.] D. Courtier-Murias, A. J. Simpson, C. Marzadori, G. Baldoni, C. Ciavatta, J. M. Fernández, E. G. López-de-Sá, C. Plaza, Unraveling the Long-Term Stabilization Mechanisms of Organic Materials in Soils by Physical Fractionation and NMR Spectroscopy, Agric. Ecosyst. Environ. 2013.

[17.] C. Plaza, J. M. Fernández, E. I. P. Pereira, A. Polo, A Comprehensive Method for Fractionating Soil Organic Matter Not Protected and Protected from Decomposition by Physical and Chemical Mechanisms, CLEAN-Soil Air Water 2012, 40, 134-139.

[18.] C. Plaza, D. Courtier-Murias, J. M. Fernández, A. Polo, A. J. Simpson, Physical, Chemical, and Biochemical Mechanisms of Soil Organic Matter Stabilization under Conservation Tillage Systems: A Central Role for Microbes and Microbial By-Products in C Sequestration, Soil Biol. Biochem. 2013, 57, 124-134.

[19.] A. J. Simpson, M. J. Simpson, E. Smith, B. P. Kelleher, Microbially Derived Inputs to Soil Organic Matter: Are current Estimates Too Low?, Environ. Sci. Technol. 2007, 41, 8070-8076.

[20.] A. Chabbi, C. Rumpel, Organic Matter Dynamics in Agro-Ecosystems - The Knowledge Gaps, Eur. J. Soil Sci. 2009, 60, 153-157.

[21.] R. Kindler, A. Miltner, M. Thullner, H.-H. Richnow, M. Kästner, Fate of Bacterial Biomass Derived Fatty Acids in Soil and Their Contribution to Soil Organic Matter, Org. Geochem. 2009, 40, 29-37.

[22.] A. Miltner, R. Kindler, H. Knicker, H.-H. Richnow, M. Kästner, Fate of Microbial Biomass-Derived Amino Acids in Soil and Their Contribution to Soil Organic Matter, Org. Geochem. 2009, 40, 978-985.

[23.] A. Miltner, P. Bombach, B. Schmidt-Brücken, M. Kästner, SOM Genesis: 
Microbial Biomass as a Significant Source, Biogeochemistry 2012, 111, 41-55.

[24.] Soil Survey Staff, Keys to Soil Taxonomy, 11th ed., USDA-Natural Resources Conservation Service, Washington, DC 2010.

[25.] A. Golchin, J. M. Oades, J. O. Skjemstad, P. Clarke, Study of Free and Occluded

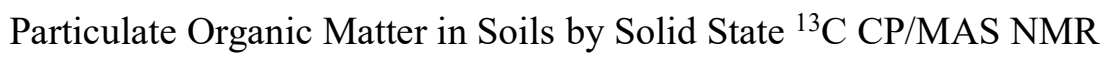
Spectroscopy and Scanning Electron Microscopy, Aust. J. Soil Res. 1994, 32, 285-309.

[26.] S. P. Sohi, N. Mahieu, J. R. M. Arah, D. S. Powlson, B. Madari, J. L. Gaunt, A Procedure for Isolating Soil Organic Matter Fractions Suitable for Modeling, Soil Sci. Soc. Am. J. 2001, 65, 1121-1128.

[27.] J. Six, E. T. Elliott, K. Paustian, Soil Macroaggregate Turnover and Microaggregate Formation: A Mechanism for C Sequestration under No-Tillage Agriculture, Soil Biol. Biochem. 2000, 32, 2099-2103.

[28.] J. Six, P. Callewaert, S. Lenders, S. De Gryze, S. J. Morris, E. G. Gregorich, E. A. Paul, K. Paustian, Measuring and Understanding Carbon Storage in Afforested Soils by Physical Fractionation, Soil Sci. Soc. Am. J. 2002, 66, 19811987.

[29.] M. Schnitzer, Organic matter characterization, in Methods of Soil Analysis, Part 2, Chemical and Microbiological Properties, 2nd ed. (Eds.: B. L. Page, R. H. Miller, D. R. Keeney), Agronomy Monograph No. 9, SSSA, Madison, WI 1982, pp. 581-594.

[30.] D. Harris, W. R. Horwath, C. van Kessel, Acid Fumigation of Soils to Remove Carbonates Prior to Total Organic Carbon or Carbon-13 Isotopic Analysis, Soil Sci. Soc. Am. J. 2001. 65, 1853-1856.

[31.] C. Ciavatta, L. Vittori Antisari, P. Sequi, A First Approach to the 
Characterization of the Presence of Humified Materials in Organic Fertilizers, Agrochimica 1988, 32, 510-517.

[32.] W. A. Ramírez, X. Domene, O. Ortiz, J. M. Alcañiz, Toxic Effects of Sigested, Composted and Thermally-Dried Sewage Sludge on Three Plants, Bioresour. Technol. 2008, 99, 7168-7175.

[33.] J. M. Fernández, N. Senesi, C. Plaza, G. Brunetti, A. Polo, Effects of Composted and Thermally Dried Sewage Sludges on Soil and Soil Humic Acid Properties, Pedosphere 2009, 19, 281-291.

[34.] J. M. Fernández, C. Plaza, A. Polo, A. F. Plante, Use of Thermal Analysis Techniques (TG-DSC) for the Characterization of Diverse Organic Municipal Waste Streams to Predict Biological Stability Prior to Land Application, Waste Manage. 2012, 32, 158-164.

[35.] G. Marando, P. Jiménez, A. Hereter, M. Julià, M. Ginovart, M. Bonmatí, Effects of Thermally Dried and Composted Sewage Sludges on the Fertility of Residual Soils from Limestone Quarries, Appl. Soil Ecol. 2011, 49, 234-241.

[36.] V. G. Franco-Otero, P. Soler-Rovira, D. Hernández, E. G. López-de-Sá, C. Plaza, Short-Term Effects of Organic Municipal Wastes on Wheat Yield, Microbial Biomass, Microbial Activity, and Chemical Properties of Soil, Biol. Fertil. Soils 2012, 48, 205-216.

[37.] P. E. Rasmussen, R. R. Allmaras, C. R. Rohde, N. C. Roager, Crop Residue Influences on Soil Carbon and Nitrogen in a Wheat-Fallow System, Soil Sci. Soc. Am. J. 1980, 44, 596-600.

[38.] A. Bhogal, F. A. Nicholson, B. J. Chambers, Organic Carbon Additions: Effects on Soil Bio-Physical and Physico-Chemical Properties, Eur. J. Soil Sci. 2009, 60, 276-286. 
379 [39.] S. Pinitpaitoon, A. Suwanarit, R. W. Bell, A Framework for Determining the 380 Efficient Combination of Organic Materials and Mineral Fertilizer Applied in $381 \quad$ Maize Cropping, Field Crops Res. 2011, 124, 302-315.

382 [40.] S. B. Wuest, H. T. Gollany, Soil Organic Carbon and Nitrogen after Application 383

[42.] K. Jindo, T. Hernández, C. García, M. A. Sánchez-Monedero, Influence of Stability and Origin of Organic Amendments on Humification in Semiarid Soils, 


\section{FIGURE CAPTIONS}

Figure 1. Free, intra-macroaggregate, intra-microaggregate, mineral-associated, dissolved, and humic acid C content in unamended soil (UN) and soil amended with either municipal solid waste compost (MC), sewage sludge compost (SC), or thermally dried sewage sludge (TS). Free, intra-macroaggregate, intra-microaggregate, mineralassociated, and dissolved organic matter $(\mathrm{OM})$ pools were isolated by physical fractionation, whereas humic acids were isolated by chemical fractionation. Error bars indicate the standard error of the mean. Within the same OM pool, different letters indicate statistically significant differences according to the Bonferroni test at the 0.05 level.

Figure 2. Free, intra-macroaggregate, intra-microaggregate, mineral-associated, dissolved, and humic acid $\mathrm{N}$ content in unamended soil (UN) and soil amended with either municipal solid waste compost (MC), sewage sludge compost (SC), or thermally dried sewage sludge (TS). Free, intra-macroaggregate, intra-microaggregate, mineralassociated, and dissolved organic matter (OM) pools were isolated by physical fractionation, whereas humic acids were isolated by chemical fractionation. Error bars indicate the standard error of the mean. Within the same OM pool, different letters indicate statistically significant differences according to the Bonferroni test at the 0.05 level.

Figure 3. $\mathrm{C} / \mathrm{N}$ ratio of free organic matter $(\mathrm{OM})$, intra-macroaggregate $\mathrm{OM}$, intramicroaggregate OM, mineral-associated OM, dissolved OM, and humic acid fraction in unamended soil (UN) and soil amended with either municipal solid waste compost (MC), sewage sludge compost (SC), or thermally dried sewage sludge (TS). Free, intramacroaggregate, intra-microaggregate, mineral-associated, and dissolved OM pools were isolated by physical fractionation, whereas humic acids were isolated by chemical 
fractionation. Error bars indicate the standard error of the mean. Within the same OM pool, different letters indicate statistically significant differences according to the Bonferroni test at the 0.05 level. 
Table 1. Mean chemical properties ( \pm standard error) of the municipal solid waste (MSW) compost, sewage sludge (SS) compost, and thermally dried SS added annually for three years $(n=3)$ and the soil before starting the field experiment $(n=4$, corresponding to composite samples collected from the 4 experimental blocks).

\begin{tabular}{lcccc}
\hline Property & MSW & SS compost & Thermally & Soil \\
& compost & & dried SS & \\
& & & & \\
\hline $\mathrm{pH}$ & $7.0 \pm 0.4$ & $7.1 \pm 0.2$ & $6.9 \pm 0.3$ & $8.5 \pm 0.0$ \\
Electrical conductivity $\left(\mathrm{dS} \mathrm{m}^{-1}\right)$ & $7.9 \pm 2.8$ & $7.6 \pm 0.1$ & $3.8 \pm 0.9$ & $0.14 \pm 0.01$ \\
Organic C $\left(\mathrm{g} \mathrm{kg}^{-1}\right)$ & $238 \pm 55$ & $140 \pm 5$ & $279 \pm 6$ & $10.3 \pm 0.2$ \\
Total N $\left(\mathrm{g} \mathrm{kg}^{-1}\right)$ & $18.4 \pm 2.2$ & $22.7 \pm 1.1$ & $43.9 \pm 1.1$ & $0.99 \pm 0.03$ \\
C/N ratio & $12.6 \pm 1.7$ & $6.2 \pm 0.1$ & $6.4 \pm 0.1$ & $10.5 \pm 0.2$ \\
\hline
\end{tabular}


Table 2. Organic $\mathrm{C}$ contents, total $\mathrm{N}$ contents, and $\mathrm{C} / \mathrm{N}$ ratios of unamended soil (UN) and soil annually amended with either municipal solid waste compost (MC), sewage sludge compost (SC), or thermally dried sewage sludge (TS) for three years, and percent of organic $\mathrm{C}$ and total $\mathrm{N}$ added with the amendment stored in soil at the end of the experiment.

\begin{tabular}{cccccc}
\hline & Organic C & Organic C & Total N & Total N stored & C/N ratio \\
& $\left(\mathrm{g} \mathrm{kg}^{-1}\right)$ & stored $(\%)$ & $\left(\mathrm{g} \mathrm{kg}^{-1}\right)$ & $(\%)$ & \\
\hline $\mathrm{UN}$ & $10.7 \pm 0.5 \mathrm{~b}$ & - & $1.14 \pm 0.03 \mathrm{~b}$ & - & $9.31 \pm 0.21 \mathrm{a}$ \\
$\mathrm{MC}$ & $14.0 \pm 0.7 \mathrm{a}$ & $34.2 \pm 3.4 \mathrm{a}$ & $1.62 \pm 0.08 \mathrm{ab}$ & $63.0 \pm 7.1 \mathrm{a}$ & $8.65 \pm 0.11 \mathrm{~b}$ \\
$\mathrm{SC}$ & $13.4 \pm 0.3 \mathrm{a}$ & $48.0 \pm 13.1 \mathrm{a}$ & $1.52 \pm 0.02 \mathrm{~b}$ & $39.8 \pm 5.2 \mathrm{~b}$ & $8.86 \pm 0.13 \mathrm{ab}$ \\
$\mathrm{TS}$ & $15.1 \pm 0.6 \mathrm{a}$ & $38.7 \pm 6.1 \mathrm{a}$ & $1.71 \pm 0.07 \mathrm{a}$ & $31.6 \pm 3.6 \mathrm{~b}$ & $8.81 \pm 0.03 \mathrm{ab}$ \\
\hline
\end{tabular}

Within columns, means followed by the same letter are not significantly different according to the Bonferroni test at the 0.05 level. 

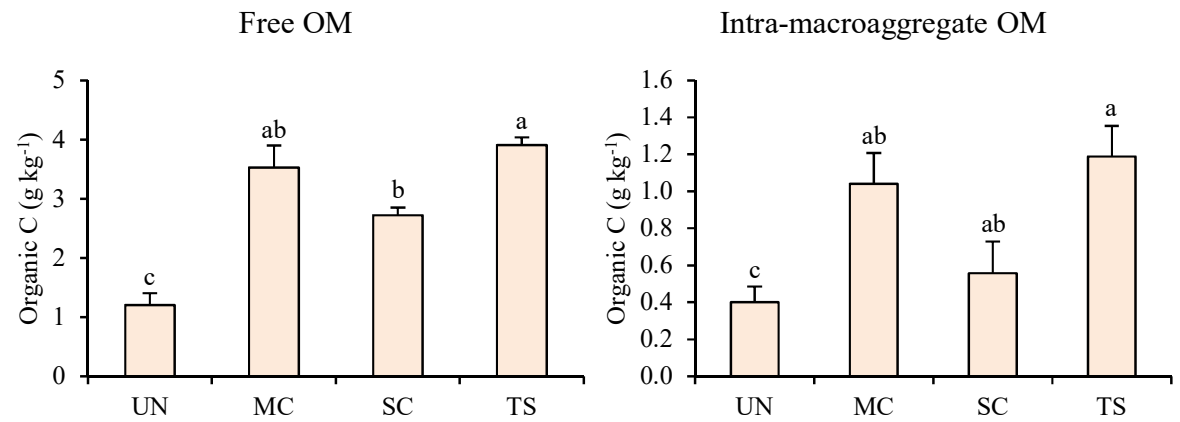

Intra-microaggregate OM

Mineral-associated OM
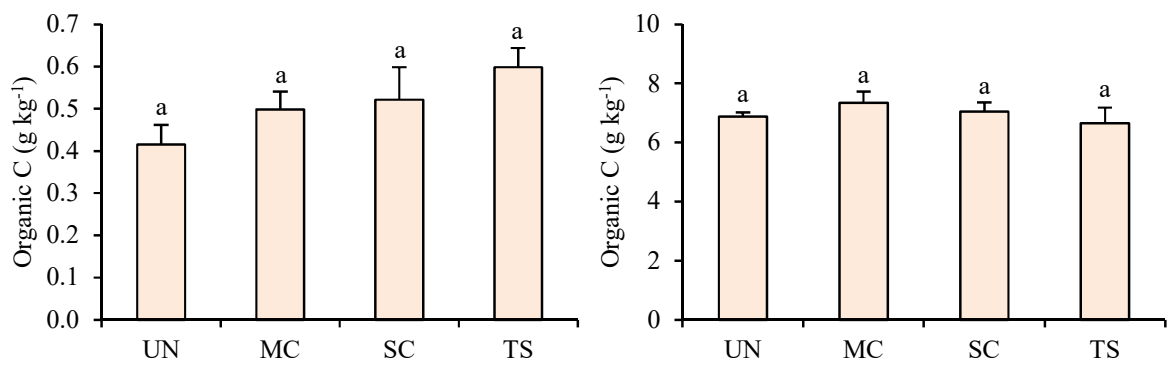

Dissolved OM

Humic acids
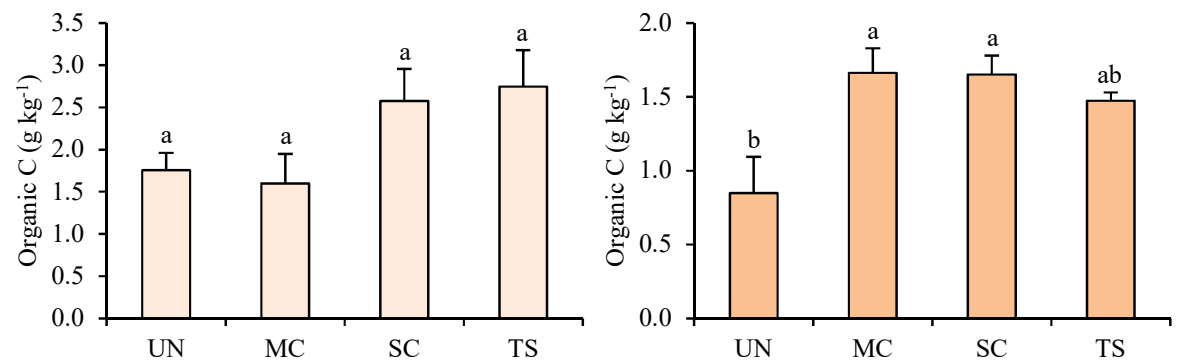
Free OM

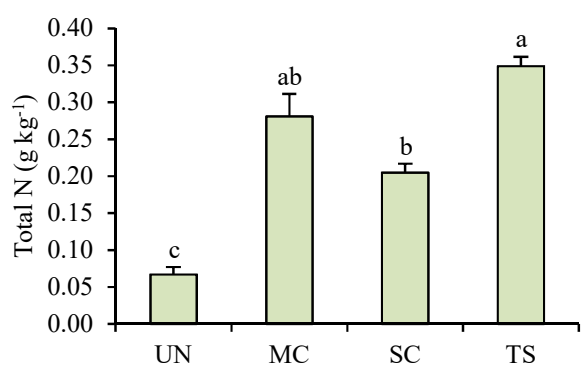

Intra-microaggregate $\mathrm{OM}$

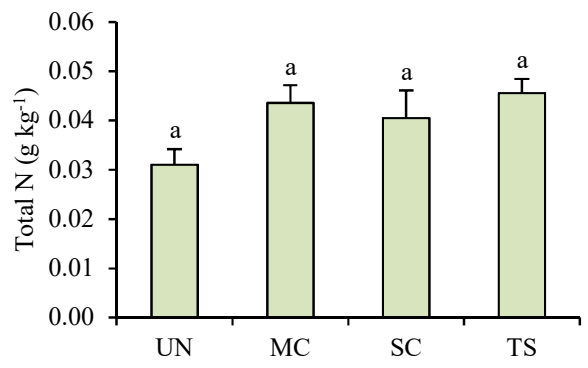

Dissolved OM

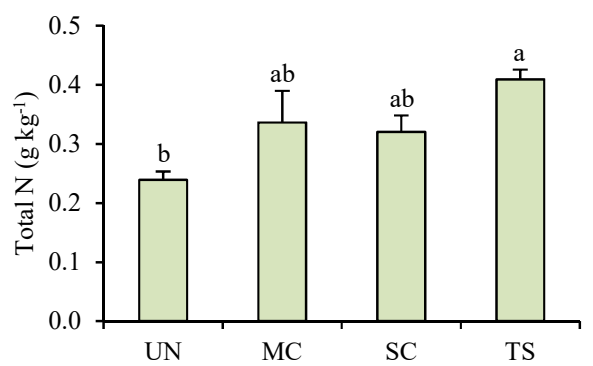

Intra-macroaggregate $\mathrm{OM}$

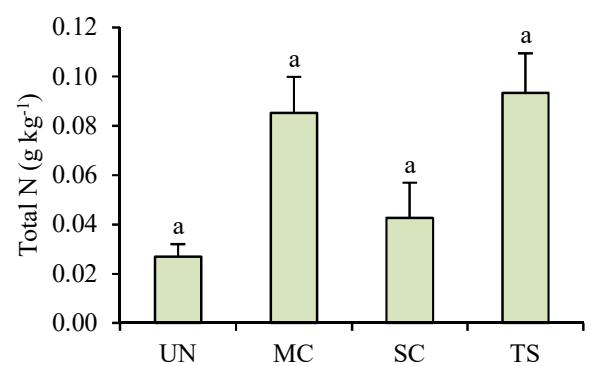

Mineral-associated OM

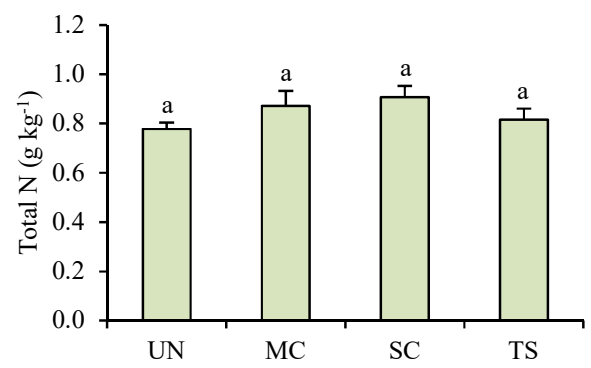

Humic acids

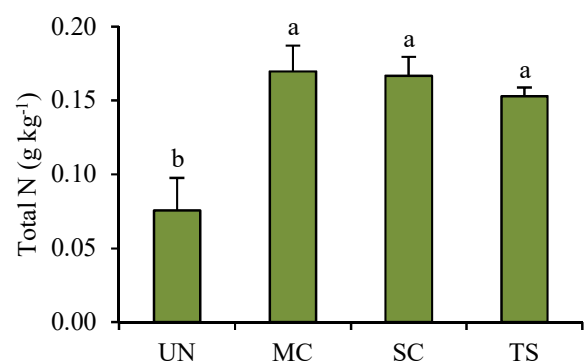


Free OM

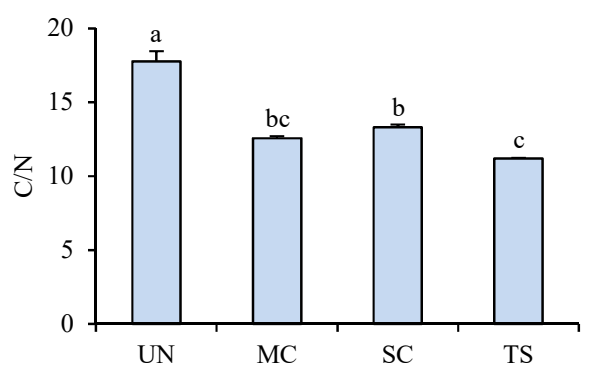

Intra-microaggregate $\mathrm{OM}$

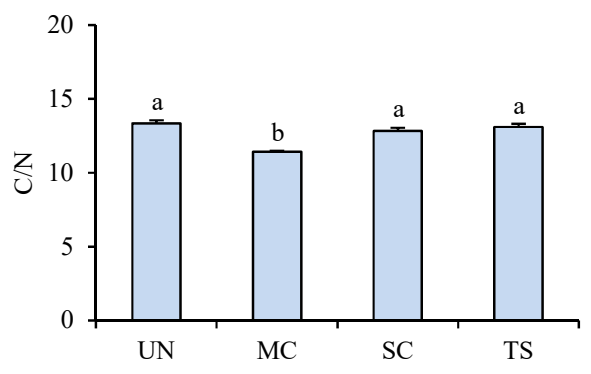

Dissolved OM

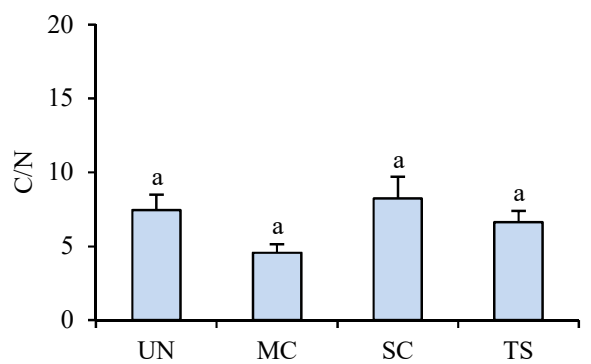

Intra-macroaggregate $\mathrm{OM}$

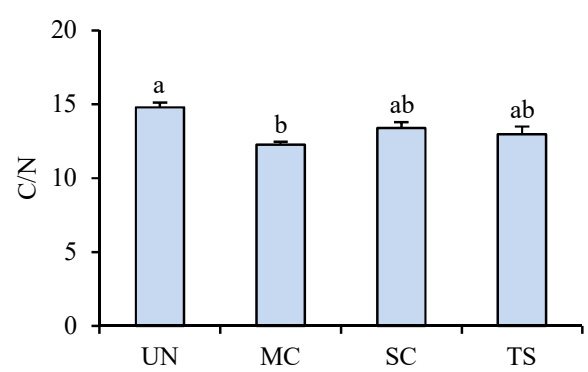

Mineral-associated OM

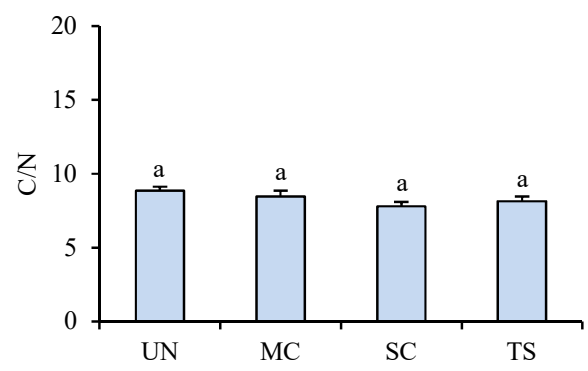

Humic acids

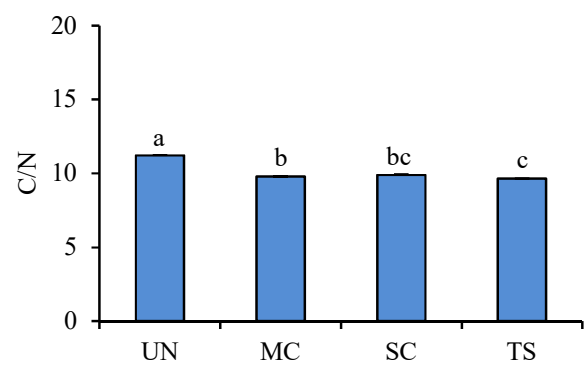




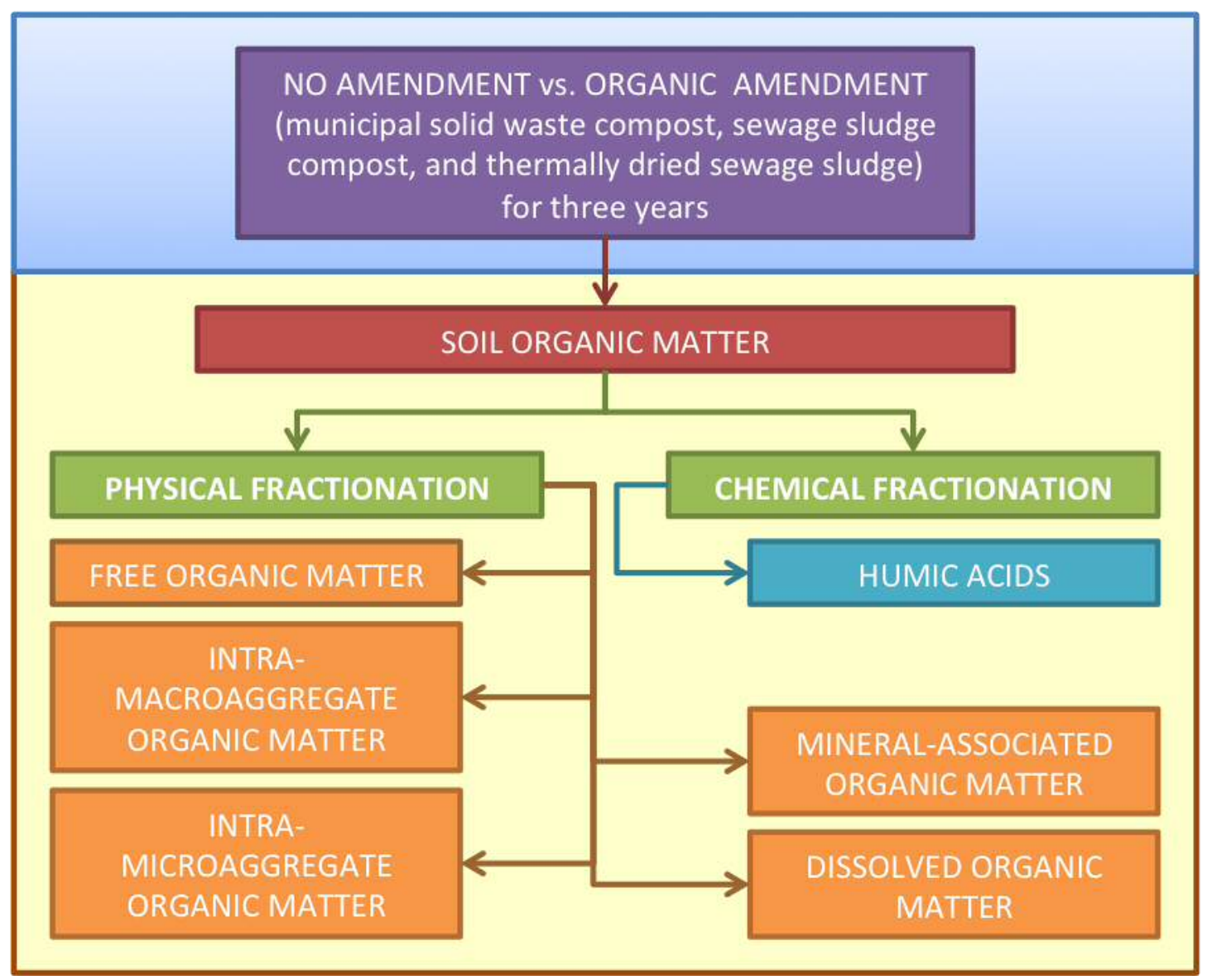

Organic $\mathrm{C}$ and total $\mathrm{N}$ distribution in organic matter pools characterized by different protection mechanisms in soils amended with different organic materials of municipal origin was investigated. After three years of annual amendment, organic inputs accumulated mostly in the physically unprotected organic matter pool, as relatively fresh, low humified materials, and secondarily in the intramacroaggregate fraction, as partially decomposed organic matter weakly protected by physical mechanisms. These results suggested that mechanisms related to strong physical protection in microaggregates and chemical inaccessibility by intimate association with minerals do not govern organic matter stabilization in the short term. 